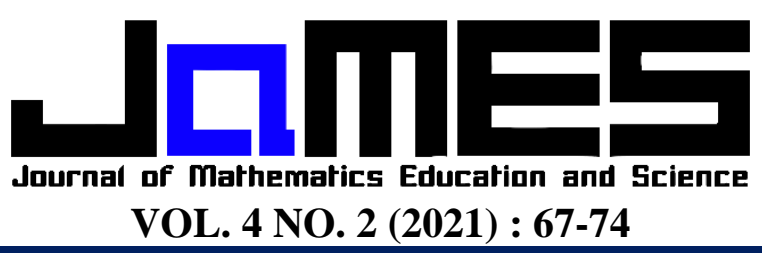

p-ISSN: 2621-1203 | https://doi.org/10.32665/james.v4i2.231

\title{
PERAMALAN INFLASI DI INDONESIA MENGGUNAKAN METODE AUTOREGRESSIVE MOVING AVERAGE (ARMA)
}

\author{
Cheryl Ayu Melyani ${ }^{1}$, Atsila Nurtsabita², Ghaitsa Zahira Shafa ${ }^{3}$, Edy Widodo ${ }^{4}$ \\ Corresponding author : G. Z. Shafa \\ Universitas Islam Indonesia, $18611001 @$ students.uii.ac.id ${ }^{1}$ \\ Universitas Islam Indonesia, 18611046@students.uii.ac.id ${ }^{2}$ \\ Universitas Islam Indonesia, 18611140@ students.uii.ac.id ${ }^{3}$ \\ Universitas Islam Indonesia, edywidodo@uii.ac.id ${ }^{4}$ \\ Received : 10 September 2021, Revised : 24 Oktober 2021, Accepted : 25 Oktober 2021 \\ (C) Mathematics Education Unugiri 2021
}

\begin{abstract}
A good inflation rate for a country is an inflation rate that has a low and stable value so that able to realize fast and controlled economic growth. Forecasting can be one of the steps that can provide an overview of the value of inflation in Indonesia for the government or related agencies to formulate and maintain inflation stability in Indonesia. In this study, a forecasting analysis was carried out to determine the prediction of inflation in Indonesia in 2021 using the Autoregressive Moving Average (ARMA) method. From the results of the research that has been done, the best model to predict this case is using the ARMA model $(3,0,0)$ because it produces the smallest AIC value of 0.2373 and the smallest RMSE of 7.81. From this model, the results of forecasting inflation rates for the months of May to December 2021 are also obtained with a range of $0.1 \%$ to $0.3 \%$. The graphic pattern of the predicted results follows the actual data line pattern, which means that this model is good to use.
\end{abstract}

Keywords : Inflation, Prediction, ARMA, AIC, RMSE

\begin{abstract}
Abstrak
Tingkat inflasi yang baik bagi suatu negara adalah tingkat inflasi yang memiliki nilai yang rendah dan stabil, sehinga mampu mewujudkan pertumbuhan ekonomi yang cepat dan terkendali. Peramalan dapat menjadi salah satu langkah yang dapat memberikan gambaran nilai inflasi di Indonesia bagi pemerintah atau badan yang terkait untuk menyusun dan mempertahankan kestabilan inflasi di Indonesia. Dalam penelitian ini, dilakukan analisis peramalan untuk mengetahui prediksi angka inflasi di Indonesia tahun 2021 menggunakan metode Autoregresif Moving Average (ARMA). Dari hasil penelitian yang telah dilakukan, model terbaik untuk meramalkan kasus ini yaitu menggunakan model ARMA $(3,0,0)$ karena menghasilkan nilai AIC paling kecil yaitu 0.2373 dan RMSE terkecil sebesar 7.81. Dari model tersebut juga didapatkan hasil peramalan angka inflasi untuk bulan Mei hingga Desember 2021 dengan kisaran 0.1\% hingga 0.3\%. Pola grafik dari hasil prediksi mengikuti pola garis data aktual yang berarti bahwa model ini baik untuk digunakan.
\end{abstract}

Kata kunci: Inflasi, Peramalan, ARMA, AIC, RMSE

\section{Pendahuluan}

Perekonomian suatu negara dapat dikatakan baik jika memiliki pertumbuhan ekonomi yang positif dan cenderung stabil [1] Salah satu indikator untuk mengukur keberhasilan perekonomian dari suatu negara adalah nilai inflasi negara tersebut. Inflasi merupakan kecenderungan kenaikan harga barang serta jasa dalam waktu yang panjang dalam perekonomian suatu negara. Demi terwujudnya pertumbuhan ekonomi yang cepat dan terkendali, tingkat inflasi dalam suatu negara atau daerah harus rendah dan stabil. Menurut Badan Pusat Statistik, laju inflasi Indonesia pada empat tahun kebelakang mengalami penurunan. Pada tahun 2017 sebesar 3,61\%, tahun 2018 turun menjadi 
$3,13 \%$, tahun 2019 turun menjadi 2,72\%, dan tahun 2020 turun kembali menjadi 1,68\% [2]

Peramalan merupakan proses memprediksi secara kuantitatif maupun kualitatif untuk melihat proyeksi kedepan berdasarkan data yang relevan pada masa lampau [3]. Dengan melakukan peramalan nilai inflasi di Indonesia pada periode kedepan, akan didapatkan angka prediksi sehingga pemerintah atau badan yang terkait dengan perekonomian dapat menyusun langkah-langkah untuk mempertahankan kestabilan inflasi di Indonesia jika prediksi nilai inflasi periode ke depan menunjukkan kenaikan [4]. Telah banyak dilakukan penelitian mengenai peramalan menggunakan peramalan time series karena kapabilitasnya dalam memprediksi suatu nilai. Salah satu metode yang sering digunakan dalam pemodelan runtun waktu untuk peramalan adalah Autoregressive Moving Average (ARMA). Agar model ARMA menghasilkan ramalan yang optimal, maka model tersebut harus memenuhi asumsi residual white noise dan berdistribusi normal. [5]

Berdasarkan latar belakang yang telah dibahas, penelitian ini memiliki tujuan untuk memprediksi angka inflasi di Indonesia tahun 2021 menggunakan metode ARMA. Dari hasil analisis ini, diharapkan dapat menjadi salah satu acuan evaluasi untuk penyusunan strategi mempertahankan kestabilan inflasi di Indonesia untuk tahun-tahun berikutnya.

\section{Metodologi Penelitian}

\subsection{Laju Inflasi}

Inflasi merupakan peristiwa dimana barang maupun jasa yang bersifat umum mengalami kenaikan harga dan terjadi terus menerus dalam waktu yang berangsur lama. Inflasi disebabkan jika kenaikan harga barang menyebar sehingga menyebabkan kenaikan harga barang lainnya. Apabila kenaikan harga tersebut terjadi hanya dalam waktu sehari atau dua hari, hal itu belum merupakan suatu inflasi karena inflasi mempunyai rentang waktu yang cukup lama [6] Tingkatan inflasi sendiri umumnya dihitung dengan menggunakan indikator dari nilai Indeks Harga Konsumen (IHK). IHK merupakan indeks yang mengukur rata-rata dari barang dan jasa yang digunakan oleh rumah tangga. Perumusan inflasi berdasarkan nilai IHK dapat dilihat sebagai berikut [7]:

$$
\text { Inflasi }=\frac{I H K_{t}-I H K_{t-1}}{I H K_{t-1}} \times 100 \%
$$

\subsection{Peramalan}

Peramalan merupakan aktivitas memprediksi sesuatu yang akan terjadi dimasa depan [3]. Menurut Subagyo, tujuan dari peramalan adalah memperoleh hasil prediksi yang dapat meminimalkan kesalahan prediksi. Data yang digunakan untuk meramalkan apa yang terjadi dimasa depan adalah data runtun waktu atau time series.

Prediksi atau peramalan (forecasting) adalah gambaran dari peristiwa di masa depan berdasarkan data masa lampau dan data saat ini. Peramalan digunakan untuk memperkirakan gambaran yang akan atau dapat terjadi di masa depan [8]. Informasi yang diperoleh dari data masa lalu dan sekarang dapat menjadi gambaran analisis bagi kejadian di masa mendatang untuk menghasilkan keputusan terbaik.

Dalam peramalan time series juga terdapat pola data yang terbentuk. Analisis time series memiliki 4 pola data yaitu pola horizontal dimana fluktuasi terjadi di sekitar nilai rata-rata stasioner atau konstan [9]. Kemudian pola trend yaitu nilai data mengalami peningkatan atau penurunan. Selanjutnya pola musiman yaitu pola perulangan yang menunjukkan adanya perubahan dari waktu ke waktu secara teratur. Dan terakhir, pola siklis yaitu berbentuk gelombang (siklus) dan mempengaruhi keadaan ekonomi lebih dari setahun.

\subsection{Autoregresif Moving Average (ARMA)}

Model Autoregressive Moving Average (ARMA) adalah salah satu model yang sangat populer dan sering digunakan dalam pemodelan data runtun waktu. Model ARMA merupakan campuran model Autoregressive yang mengasumsikan data sekarang dipengaruhi oleh data sebelumnya dan Moving Average yang mengasumsikan data sekarang dipengaruhi oleh nilai residual data sebelumnya. Sedangkan runtun waktu adalah susunan observasi yang dicatat berurut berdasarkan waktu. Model ARMA diperkenalkan oleh George Edward Pelham Box dan Gwilym Meirion Jenkins (1976).Oleh karena itu pembentukan model ARMA juga sering disebut metode runtun waktu Box-Jenkins.

Model dari Autoregressive Model (AR) yang dinotasikan dengan $\mathrm{AR}(\mathrm{p})$ dinyatakan sebagai berikut:

$$
y_{t}=b_{0}+b_{1} y_{t-1}+b_{2} y_{t-2}+\cdots+b_{n} y_{t-n}+\varepsilon_{t}
$$


Model Moving Average (MA) yang dinotasikan dengan MA(q) dinyatakan sebagai berikut:

$y_{t}=\alpha_{0}-\alpha_{1} \varepsilon_{t-1}+\alpha_{2} \varepsilon_{t-2}+\cdots+\alpha_{n} \varepsilon_{t-n}+\varepsilon_{t}$

dengan:

$y_{t}$ : nilai runtutan yang bersifat stasioner

$y_{t-1}$ : merupakan nilai lampu runtunan

$y_{t-2}$ : merupakan nilai lampu runtunan

$\varepsilon_{t-1}, \varepsilon_{t-2} \ldots \varepsilon_{t-n}, \varepsilon_{t}$ : residual

$\alpha_{0}, \alpha_{1}, \alpha_{2} \ldots \alpha_{n}$ : konstanta dan koefisien MA

$b_{0}, b_{1}, b_{2} \ldots b_{n}$ : konstanta dan koefisien AR [10]

\subsection{Uji Stasioneritas}

Stasioneritas data merupakan salah satu asumsi yang harus terpenuhi dalam peramalan. Dalam kestasioneran data sendiri terbagi menjadi dua, yaitu data yang telah stasioner dan data tidak stasioner. Data tidak stasioner sendiri terbagi menjadi tiga yaitu data tidak stasioner dalam ratarata, tidak stasioner dalam variansi, serta tidak stasioner dalam rata-rata dan variansi. Ketika dilihat dengan menggunakan plot, data yang tidak stasioner dalam rata-rata akan membentuk trend tidak datar pada sumbu horizontal. Untuk data yang tidak stasioner dalam variansi, plot akan membentuk trend datar namun membangun pola melebar atau menyempit. Sedangkan untuk tidak stasioner dalam keduanya yaitu pola membentuk trend tidak datar sekaligus membentuk pola terompet [11].

Beberapa metode untuk mengetahui stasioneritas data adalah dengan melihat dari pola grafik untuk mengetahui grafik telah konstan. Kemudian dengan uji correlogram menggunakan fungsi Autocorrelation Function (ACF) dan Partial Autocorrelation Function (PACF) untuk menelaah signifikansi autokorelasi dan kestastioneran data, dan uji akar unit Augmented Dicky Fuller Test (ADF) dengan mempertimbangkan adanya autokorelasi yang terjadi dalam error term saat series yang digunakan merupakan nonstasioner [12]. Berikut merupakan persamaan uji ADF [13]:

$$
\begin{aligned}
& \Delta Y_{t}=b_{0}+\theta y_{t-1}+{ }_{i=2}^{p} \phi \Delta y_{t_{-1 i}}+\varepsilon_{t} \\
& \text { dengan: } \\
& y_{t}: \text { nilai runtun waktu pada waktu ke-t } \\
& \theta \text { : konstanta bernilai }\left(b_{1}+\cdots+b_{p-1}-1\right) \\
& \text { yang digunakan untuk menentukan ada } \\
& \text { knya } \text { unit root. } \\
& \phi_{i}: \text { koefisien trend }
\end{aligned}
$$
tidaknya unit root.
Dimana pada saat statistik uji $t_{\text {hitung }}>t_{\text {tabel }}$, maka akan menolak $\mathrm{H}_{0}$ yang menyatakan bahwa data stasioner.

\subsection{Uji Diagnostik Model}

Pemeriksaan kelayakan model dilakukan untuk mengetahui dan membuktikan bahwa model ARMA layak digunakan. Uji Ljung-Box $(Q)$ dapat digunakan untuk menguji kelayakan model dengan hipotesis sebagai berikut [14]:

$\mathrm{H}_{0}: \hat{\rho}_{k}=0$ (Residual adalah white noise)

$\mathrm{H}_{1}: \hat{\rho}_{k} \neq 0$ (Residual tidak white noise)

Statistik uji:

$$
Q=n(n+2) \sum_{K=1}^{K} \frac{\left(\hat{\rho}_{k}\right)^{2}}{(n-K)}
$$

dengan:

$\hat{\rho}_{k}$ : koefisien autokorelasi sisaan pada lag ke- $k$

$K$ : lag maksimum

$n$ : banyak pengamatan

Daerah penolakan yaitu tolak $\mathrm{H}_{0}$ jika $Q>$ $\chi_{a ; d f=k-p-q}^{2}$ atau tolak $\mathrm{H}_{0}$ jika $p$-value lebih dari $\alpha$ yang memiliki arti bahwa autokorelasi sisaan tidak signifikan.

\subsection{Akaike Information Criterion (AIC)}

Dalam menguji ketepatan suatu model, seorang ahli statistik yaitu Profesor Hirotu Akike mengusulkan suatu metode yaitu Akaike Information Criterion (AIC). Nilai AIC dapat dihitung sebagai berikut [15]:

dengan:

$$
A I C=\log \left(\frac{\sum\left(e_{i}\right)^{2}}{n}+\left(\frac{2 k}{n}\right)\right.
$$

$e_{i}^{2}:$ residual kuadrat

$k:$ jumlah parameter

$n$ : banyak pengamatan

Untuk memilih model ARMA terbaik, digunakan hasil perhitungan nilai AIC yang didapatkan untuk tiap modelnya. Nilai AIC terkecil merupakan aspek untuk menentukan model ARMA terbaik untuk peramalan [16].

\subsection{Root Mean Square Error (RMSE)}

RMSE merupakan perhitungan kesalahan dari nilai besarnya rata-rata error pada suatu pengamatan, sehingga RMSE biasa digunakan untuk mengetahui besar kesalahan pada data dari model [17]. RMSE dapat dihitung dengan menggunakan rumus berikut: 


$$
R M S E=\sqrt{\frac{\sum_{i}^{n}\left(\hat{x}-x_{i}\right)^{2}}{n}}
$$

dengan:

$\hat{x}$ : nilai hasil peramalan

$x_{i}$ : nilai objek pengamatan ke- $i$

$n$ : banyaknya data

\subsection{Metode}

Data yang digunakan pada penelitian ini merupakan data sekunder yang diperoleh dari website Badan Pusat Statistika https://www .bps.go.id/. Penelitian ini menggunakan data Inflasi bulanan Indonesia dari tahun 2015 sampai tahun 2020. Data diakses pada tanggal 27 April 2021. Variabel yang digunakan adalah nilai inflasi di Indonesia. Metode penelitian yang digunakan adalah studi literatur, dimana peneliti mempelajari beberapa sumber seperti buku, makalah, jurnal, dan berbagai contoh makalah penelitian. Untuk menentukan model dan melakukan peramalannya peneliti menggunakan metode ARMA dengan bantuan softtware RStudio. Alur dari penelitian ini digambarkan melalui flowchart yang disaikan dalam Gambar 1.

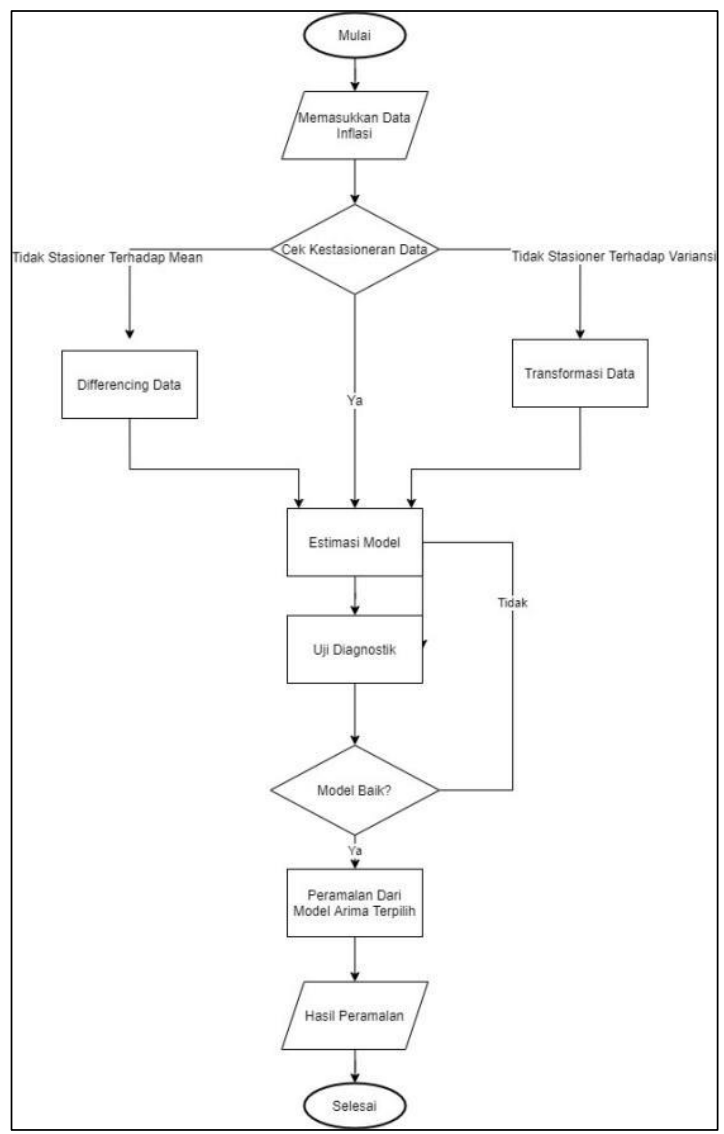

Gambar 1 Flowchart

\section{Pembahasan}

\subsection{Analisis Deskriptif}

Gambaran karakteristik data Inflasi bulanan Indonesia dari tahun 2015 sampai tahun 2020 disajikan pada Tabel 1.

Tabel 1. Data Inflasi di Indonesia

\begin{tabular}{lcccccc}
\hline \multicolumn{1}{c}{ Bulan } & \multicolumn{7}{c}{ Tahun } \\
\cline { 2 - 7 } & 2015 & 2016 & 2017 & 2018 & 2019 & 2020 \\
\hline Januari & $-0,24$ & 0,51 & 0,97 & 0,62 & 0,32 & 0,39 \\
Februari & $-0,36$ & $-0,09$ & 0,23 & 0,17 & $-0,08$ & 0,28 \\
Maret & 0,17 & 0,19 & $-0,02$ & 0,20 & 0,11 & 0,10 \\
April & 0,36 & $-0,45$ & 0,09 & 0,10 & 0,44 & 0,08 \\
Mei & 0,50 & 0,24 & 0,39 & 0,21 & 0,68 & 0,07 \\
Juni & 0,54 & 0,66 & 0,69 & 0,59 & 0,55 & 0,18 \\
Juli & 0,93 & 0,69 & 0,22 & 0,28 & 0,31 & $-0,10$ \\
Agustus & 0,39 & $-0,02$ & $-0,07$ & $-0,05$ & 0,12 & $-0,05$ \\
September & $-0,05$ & 0,22 & 0,13 & $-0,18$ & $-0,27$ & $-0,05$ \\
Oktober & $-0,08$ & 0,14 & 0,01 & 0,28 & 0,02 & 0,07 \\
November & 0,21 & 0,47 & 0,20 & 0,27 & 0,14 & 0,28 \\
Desember & 0,96 & 0,42 & 0,71 & 0,62 & 0,34 & 0,45 \\
\hline
\end{tabular}

Berdasarkan Tabel 1, terlihat bahwa data yang ditandai dengan warna merah merupakan nilai minimum dari data inflasi Indonesia dari Januari 2015 sampai Desember 2020 adalah -0,45. Hal ini berarti bahwa pada bulan April 2016, Indonesia mengalami deflasi tertinggi. Sedangkan data yang berwarna biru menunjukkan nilai maksimum sebesar 0,97. Dimana pada bulan Januari 2017, Indonesia mengalami inflasi tertinggi.

Gambaran rata-rata inflasi di Indonesia tahun 2016 sampai tahun 2020 dapat dilihat dari grafik yang ditampilkan pada Gambar 2.

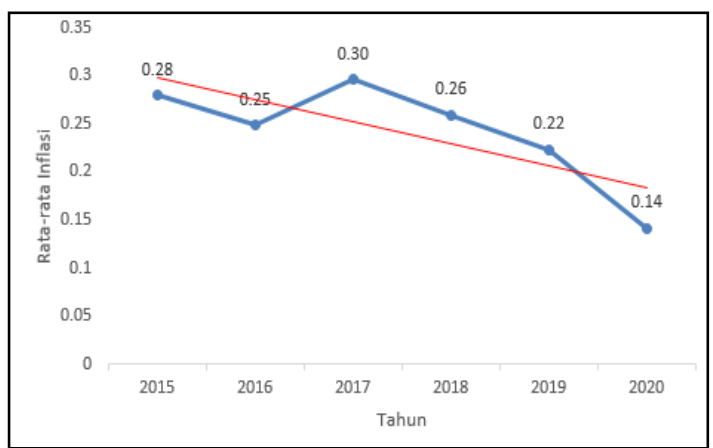

Gambar 2 Grafik Rata-rata Inflasi di Indonesia Tahun 2015-2020

Berdasarkan Gambar 2, terlihat pola inflasi dari tahun 2015 hingga tahun 2020. Dari kurun waktu 6 tahun terakhir, terjadi penurunan rata-rata inflasi di Indonesia dengan melihat trendline yang disajikan dalam garis berwarna merah dimana garis tersebut membentuk trendline turun. Rata-rata inflasi 
tertinggi terjadi pada tahun 2017 yakni sebesar $0,3 \%$, setelah itu terus menurun hingga tahun 2020 sebesar $0,14 \%$.

\subsection{Uji Stasioneritas Data}

Uji stasioneritas data dilakukan untuk mengetahui apakah data telah stasioner atau belum, yang mana uji ini merupakan asumsi yang harus dipenuhi untuk melakukan peramalan dengan model ARMA. Pengujian stasioneritas data dilakukan menggunakan plot data dan uji hipotesis ADF yang disajikan dalam Gambar 3 .

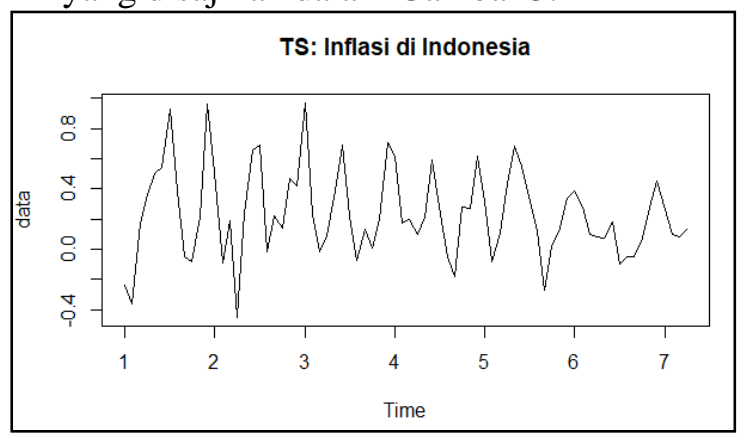

Gambar 3. Plot data inflasi

Gambar 3 merupakan plot dari data inflasi di Indonesia dari tahun 2015 hingga 2020. Dapat dilihat bahwa dalam jangka waktu tersebut plot menunjukkan pola pergerakan yang stasioner, Kemudian dilanjutkan uji stasioneritas menggunakan uji ADF yang hasilnya disajikan dalam Tabel 2.

Tabel 2. Uji Stasioneritas

\begin{tabular}{ccc}
\hline Statistik Uji & $\boldsymbol{P}$-value & Keputusan \\
-5.6735 & 0,01 & Tolak $\mathrm{H}_{0}$ \\
\hline
\end{tabular}

Dari hasil pengujian stasioneritas tersebut, didapatkanlah nilai statistik uji -5.6735 dan $p$-value sebesar 0,01 yang mana menunjukkan bahwa data yang ada menolak $H_{0}$. Sehingga, didapatkanlah keputusan bahwa data tersebut data telah stasioner.

\subsection{Peramalan Model ARMA}

Pada peramalan menggunakan metode ARMA, dilakukan tahapan identifikasi model dengan cara melihat pola data menggunakan grafik ACF yang mengindikasikan model AR dan PACF yang mengindikasikan model MA. Hasil dari identifikasi model menggunakan grafik ACF dan PACF ditampilkan pada Gambar 4.

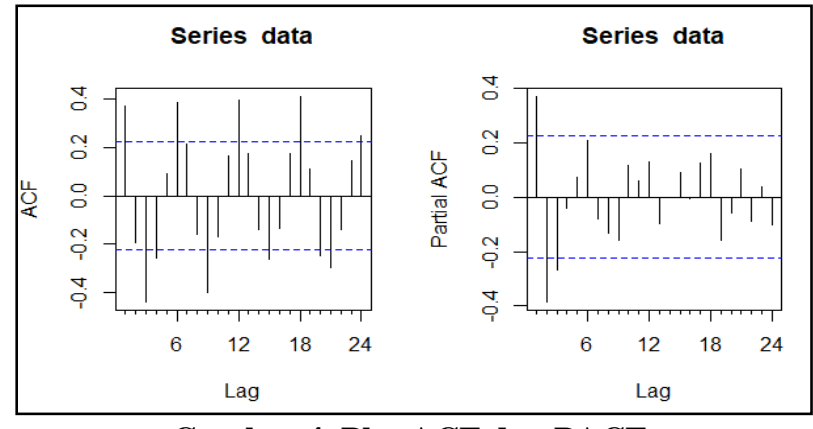

Gambar 4. Plot ACF dan PACF

Berdasarkan Gambar 4, diketahui bahwa dari plot ACF pada jumlah 4 lag pertama, lag pertama keluar garis. Hal tersebut menunjukkan bahwa order MA yaitu $\mathrm{q}=1$. Sementara pada plot PACF, garis yang keluar garis pada 4 lag pertama didapati sebanyak 3. Dengan demikian, diketahui bahwa order AR yaitu $p=3$. Dalam kasus ini tidak dilakukan diferensiasi ataupun transformasi dikarenakan data sudah stasioner, sehingga untuk order $\mathrm{d}=0$.

Model utama yang terbentuk adalah ARMA $(3,0,1)$. Pendugaan terhadap model lain dilakukan dengan mengkombinasikan order pada model utama atau menggunakan order yang lebih rendah dari model utama. Dalam penelitian kali ini, peneliti melakukan overfitting pada 7 model. Maka model tersebut dipilih menjadi model1: ARMA $(2,0,1)$, model2: ARMA $(1,0,1)$, model3: ARMA $(1,0,0)$, model4: ARMA $(0,0,1)$, model5: ARMA $(2,0,0)$, model6: ARMA $(3,0,1)$, dan model7: ARMA $(3,0,0)$, Selanjutnya diperoleh rangkuman dari hasil ke-lima model yang signifikan sebanyak 5 model. Hasil rangkuman model signifikan ditampilkan dalam Tabel 3.

Tabel 3. Model Signifikan,

\begin{tabular}{cccc}
\hline Model & AIC & RMSE & Keputusan \\
\hline ARMA $(2,0,1)$ & 9,65 & 0,2403 & Signifikan \\
\hline ARMA $(1,0,0)$ & 22,45 & 0,2693 & Signifikan \\
\hline ARMA $(0,0,1)$ & 18,23 & 0,2618 & Signifikan \\
\hline ARMA $(2,0,0)$ & 12,53 & 0,2485 & Signifikan \\
\hline ARMA $(3,0,0)$ & 7,81 & 0,2373 & Signifikan \\
\hline
\end{tabular}

Untuk menentukan model terbaik dapat diketahui dari nilai AIC dan nilai RMSE yang disajikan dalam Tabel 3. Model yang memiliki hasil nilai AIC dan RMSE terkecil adalah model terbaik, Berdasarkan rangkuman di atas, dapat diketahui bahwa nilai AIC dan nilai RMSE terkecil terdapat pada model ARMA $(3,0,0)$ yaitu sebesar 7,81 dan 0,2373 . 
Selanjutnya, melihat residual dari model yang telah dipilih yaitu model terbaik dengan melakukan uji diagnostik. Hasil dari uji diagnostik disajikan dalam Gambar 5.

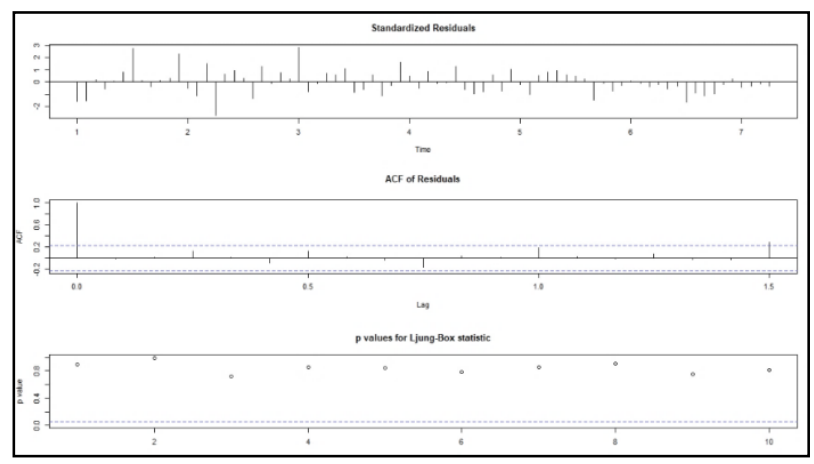

Gambar 5. Plot uji diagnostik

Berdasarkan hasil plot uji diagnostik, bahwa p-value dari Ljung-box statistic berada diatas garis di mana lebih dari 0,05 dan tidak ada garis yang keluar dari batas pada ACF of Residuals sehingga, Sehingga dapat dikatakan bahwa residu dari model ini sudah mengikuti white noise. Setelah mendapat model terbaik, selanjutnya dilakukan peramalan untuk 8 periode ke depan dengan hasil peramalan dan plot data dari hasil model terbaik yang disajikan dalam Gambar 6 dan Gambar 7.

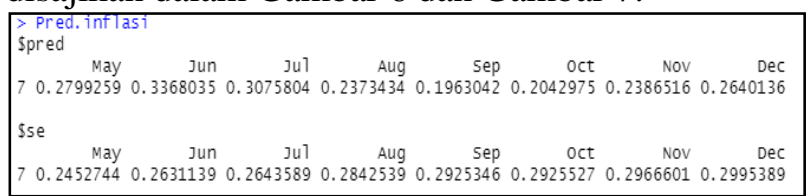

Gambar 6. Hasil Peramalan

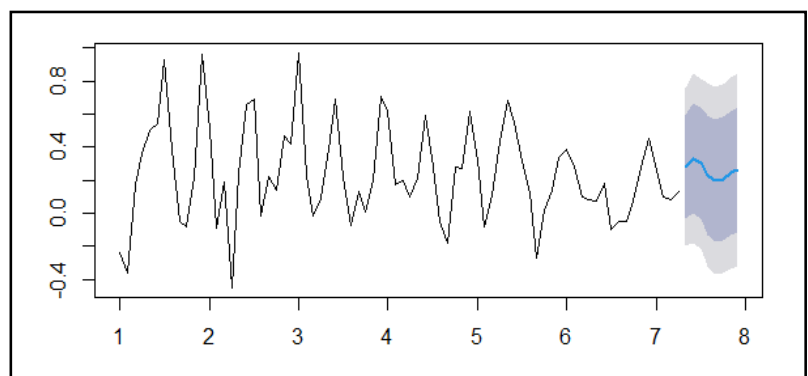

Gambar 7. Output grafik peramalan menggunakan model terbaik

Berdasarkan Gambar 6, didapatkan prediksi nilai inflasi di Indonesia untuk 8 periode kedepan, yaitu bulan Mei hingga Desember 2021. Pada bulan Mei 2021 diprediksi nilai inflasi sebesar 0,28\%, bulan Juni 2021 diprediksi nilai inflasi sebesar $0,34 \%$, bulan Juli 2021 diprediksi nilai inflasi sebesar 0,31\%, bulan Agustus 2021 diprediksi nilai inflasi sebesar $0,24 \%$, bulan
September 2021 diprediksi nilai inflasi sebesar 0,20\%, bulan Oktober 2021 diprediksi nilai inflasi sebesar 0,20\%, bulan November 2021 diprediksi nilai inflasi sebesar $0,24 \%$, dan bulan Desember 2021 diprediksi nilai inflasi sebesar $0,26 \%$.

Dari hasil prediksi yang dicantumkan pada Gambar 7 , dapat dilihat dari grafik bahwa pola grafik hasil prediksi mengikuti pola garis data aktual yang berarti bahwa model ini baik untuk digunakan dan sesuai dengan data aktual dengan menggunakan model ARMA (3,0,0). Model tersebut menghasilkan nilai perhitungan kesalahan RMSE sebesar 0,2373.

\section{Penutup}

Berdasarkan hasil analisis dan pembahasan dari analisis yang dilakukan, kesimpulan yang dapat diambil adalah sebagai berikut:

a. Pergerakan inflasi di Indonesia dari tahun 2015 sampai tahun 2020 menunjukkan trendline turun yang berarti terjadi penurunan rata-rata inflasi di Indonesia, dimana pada tahun 2020 ini merupakan inflasi terendah jika dilihat dari tahun-tahun sebelumnya.

b. Model ARMA $(3,0,0)$ adalah model terbaik karena memiliki nilai AIC paling kecil yaitu sebesar 0,2373 dan RMSE terkecil sebesar 7,81. Berdasarkan hasil prediksi yang dilakukan menggunakan model ARMA $(3,0,0)$, maka didapatkanlah pada bulan Mei hingga Desember 2021, Pada bulan Mei 2021 diprediksi nilai inflasi sebesar 0,28\%, bulan Juni 2021 diprediksi nilai inflasi sebesar $0,34 \%$, bulan Juli 2021 diprediksi nilai inflasi sebesar $0,31 \%$, bulan Agustus 2021 diprediksi nilai inflasi sebesar 0,24\%, bulan September 2021 diprediksi nilai inflasi sebesar $0,20 \%$, bulan Oktober 2021 diprediksi nilai inflasi sebesar $0,20 \%$, bulan November 2021 diprediksi nilai inflasi sebesar 0,24\%, dan bulan Desember 2021 diprediksi nilai inflasi sebesar 0,26\%.

\section{Referensi}

[1] Silfiani, M., \& Suhartono. (2012). Aplikasi Metode Ensembel untuk Peramalan Inflasi di Indonesia. Jurnal Sains Dan Seni ITS, 171-176.

[2] Badan Pusat Statistik. ARIMA (Auto regressive Integrated Moving Average). diambil dari daps.bps.go.id: https://daps.bps.go.id/fileartike 1/77/arima,pdf pada tanggal, 25 Mei 2021.

[3] Fahrudin, R., \& Sumitra, I. D. Peramalan 
Inflasi Menggunakan Metode SARIMA dan Single Exponential Smoothing (Studi Kasus: Kota Bandung). Majalah Ilmiah UNIKOM, (2020) 111-120.

[4] Santoso, Teguh, \& Kharisma, Bayu. Peramalan Inflas Kota Bandung dengan Pendekatan Box-Jenkins. Buletin Studi Ekonomi Vol.25 No.2, (2020).

[5] Maswar. Analisis Time Series Model ARMA untuk Memprediksi Jumlah Santri PP Salafiyah Syafi'iyah Sukorjo 20172021. Jurnal Lisan Al-Hal Volume 11, No.1, (2017).

[6] Simanungkalit, Erika Feronika Br., Pengaruh Inflasi Terhadap Pertumbuhan Ekonomi di Indonesia. Journal of Management (SME's) (2020) Vol.13, No.3.

[7] Silfiani, M., \& Suhartono, Aplikasi Metode Ensembel untuk Peramalan Inflasi di Indonesia. Jurnal Sains Dan Seni ITS, (2012) 171-176.

[8] Bustami, H, I., \& Gamal, M, D., Holt-Winters Forecasting Method That Takes in to Account the Effect of Eid. Science Journal of Applied Mathematics and Statistics, (2015) 257-262.

[9] Nawangwulan, S., \& Angesti, D. Analisis TIme Series Metode WInter Jumlah Penderita Gastroenteritis Rawat Inap Berdasarkan Data Rekam Medis Di RSUD Dr. Soetomo. Jurnal Manajemen Kesehatan STIKES yayasan RS Dr. Soetomo, (2016) 17-32.
[10] Tusyakdiah, H. Penerapan Metode Autoregressive Integrated Moving. diambil dari https://halimatusyak,medium,com/penera pan-metode-auto-regressive-integratedmoving -average-arima-pada-peramalan-harga-bitcoin77558605eaf5 pada tanggal, 25 Mei 2021

[11] Mulyana. Buku Ajar Analisis Deret Waktu. Universitas Padjajaran FMIPA Jurusan Statistika, Bandung, (2004).

[12] Aktivani, S. Uji Stasioneritas Data Inflasi Kota Padang Periode 2014-2019. Statistika, (2020), Vol.20, No.20.

[13] Gujarati, D. N. Basic Econometrics. 4th Edition. The McGraw-Hill Companies. (2004).

[14] Wei, W. W. S. Time Series: Univariate and Multivariate Methods. Redwood City, Calif: Addison-Wesley. (1990).

[15] Widarjono, A. Ekonometrikas Teori dan Aplikasi Untuk Ekonomi dan Bisnis. Ekonisia Fakultas Ekonomi Universitas Islam Indonesia. Yogyakarta. (2005).

[16] As'ad, M., Wibowo, S, S., \& Sophia, E. Peramalan Jumlah Mahasiswa Baru Dengan Model Autoregressive Integrated Moving Average (ARIMA), Jurnal Informatika Merdeka Pasuruan, (2017) Vol.2 No.3, 20-33,

[17] Cort, W, J., \& Kenji, M. Advantages of the Mean Absolute Error (MAE) Over the Root Mean Square Error (RMSE) in Assessing Average Model Performance. Department of Geography University of Delaware, Newark, (2005). 
http://journal.unugiri.ac.id/index.php/JaMES 